\title{
GAMBARAN PROGRAM PROMOSI JABATAN, PENGHARGAAN DAN KEPUASAN KERJA KARYAWAN PT. GUNANUSA UTAMA FABRICATORS SERANG
}

\author{
Dwi Ervita Sari \\ Universitas Pendidikan Indonesia \\ dwi.ervita.sari@student.upi.edu \\ Syamsul Hadi Senen \\ Universitas Pendidikan Indonesia \\ syamsulhadisenen@upi.edu \\ Girang Razati \\ Universitas Pendidikan Indonesia \\ girangrazati@upi.edu
}

\begin{abstract}
ABSTRAK
Tujuan - Tujuan penelitian ini adalah untuk melihat gambaran promosi jabatan, penghargaan dan kepuasan kerja

Desain/metodologi/pendekatan - Desain penelitian ini adalah cross sectional method. Penelitian ini menggunakan pendekatan deskriptif dengan metode explanatory survei. Sebanyak 90 responden dipilih dengan menggunakan probability sampling. Sebuah angket digunakan sebagai instrumen penelitian untuk mengumpulkan data dari responden. Teknik analisis yang digunakan adalah teknik deskriptif dengan menggunakan distribusi frekuensi.

Temuan - Berdasarkan hasil penelitian menggunakan analisis deskriptif, didapatkan hasil bahwa promosi jabatan katagori cukup baik dengan skor 7396 diperoleh persentase sebesar 73,37\%, penghargaan dalam katagori cukup sesuai dengan skor 12118 diperoleh persentase sebesar 73,98\%. dan kepuasan kerja berada dalam kategori cukup tinggi dengan skor 12769 diperoleh persentase sebesar 75,06\%.

Orisinalitas/nilai - Penelitian ini memberikan dasar untuk memahami isu-isu promosi jabatan, penghargaan dan kepuasan kerja. Perbedaan penelitian ini dengan penelitian sebelumnya adalah terletak pada objek yang merupakan perusahaan dalam industri kontruksi yaitu PT. Gunanusa Utama Fabricators Serang, dengan variabel yang diteliti yaitu promosi jabatan, penghargaan dan kepuasan kerja, serta menggunakan teori atau referensi yang berbeda dengan peneliti sebelumnya.
\end{abstract}

Kata Kunci: Program Promosi Jabatan, Penghargaan dan Kepuasan Kerja

Jenis Artikel: Studi Kasus

\begin{abstract}
Purpose - The purpose of this study is to see the description of promotion program, reward and job satsfaction. Design/methodology/approachh - The design of this study was cross sectional method. This research uses descriptive approach with explanatory survey method. A total of 90 respondents were selected using probability sampling. A questionnaire was used as a research instrument to collect data from respondents. Analytical technique used is descriptive technique by using frequency distribution.

Findings - Based on the results of the research using descriptive analysis, the results obtained result that promotion of good enough position with score 7396 acquisition equal to 73,37\%, amount in category enough according to score 12118 , obtained percentage equal to $73,98 \%$. and job satisfaction in high enough category with score 12769 Earnings equal to $75,06 \%$.

Originality/value - This study provides a basis for understanding issues of promotion program, reward and job satsfaction. The difference of this study with the previous research is located on the object which is the company in the contuction industry that is PT. Gunanusa Utama Fabricators Serang, with the variables studied namely promotion program, reward and job satsfaction, and using different theory or reference from previous researcher.
\end{abstract}

Keywords: promotion program, reward and job satsfaction

Article Type : Case Study 


\section{PENDAHULUAN}

Sumber daya manusia sebagai bagian esensial dari perusahaan atau organisasi yang harus diperhatikan agar karyawan sebagai bagian dari SDM dapat memberikan kontribusinya secara optimal (Senen, Sumiyati, \& Masharyono, 2016), dan dipandang sebagai faktor dan dianggap lebih penting dalam mencapai keunggulan kompetitif (Marchington, Wilkinson, \& Donnelly, 2016) namun untuk mencapai tujuan secara efektif diperlukan manajemen yang baik dan benar (Wibowo, 2014). Dalam hal ini, manajemen perusahaan harus mendorong karyawannya agar dapat memaksimalkan kinerja untuk mencapai tujuan perusahaan, maka perusahaan perlu memberikan pengarahan kepada karyawan dalam melaksanakan setiap tugasnya (Senen \& Widyanata, 2016).

Dalam membantu penetapan tujuan dengan adanya bantuan sebagai peran yang sangat strategis dalam meningkatkan kualitas sumber daya manusia (Ramadhanti, Mulyadi, \& Razati, 2016). Oleh karena itu manajemen SDM dianggap sebagai filosofi tentang bagaimana karyawan harus dikelola, yang didukung oleh sebuah angka teori yang berkaitan dengan perilaku karyawan dan organisasi atau perusahaan (Armstrong, 2014), sumber daya manusia tersebut harus menjadi perhatian untuk dikembangkan secara maksimal.

Suatu perusahaan tanpa di dukung karyawan yang sesuai dengan baik segi kuantitatif, kualitatif, strategi, operasional, dan fungsi maka perusahaan itu tidak akan mampu bertahan keberadaan, menegmbangkan, dan kemajuannya di masa yang akan datang, hal tersebut menjadi tolak ukur untuk penilaian kualitas pengalaman bekerja seperti yang disebutkan oleh (Locke, 1976; Shyam Singh, 2016). Beberapa dekade terakhir, para peneliti untuk terus menerus untuk meningkatkan kepuasan kerja (Masood, Aslam, \& Rizwan, 2014), kepuasan kerja menjadi isu yang paling penting dalam perusahaan (Kennedy \& Gray, 2015). Karyawan yang memiliki kepuasan kerja muncul ketika harapan seseorang terpenuhi, harapan itu berupa kebutuhan dan keinginan karyawan, jika kepuasan kerja karyawan rendah akan menjadi tanggung jawab organisasi dalam membina praktek kualitas HRM mempengaruhi hasil bisnis apabila kepuasan kerja rendah akan menimbulkan ketidakpuasan bagi karyawan sehingga kinerjanya menurun (Singh \& Loncar, 2017).

Banyak penelitian menunjukkan kepuasan kerja karyawan yang rendah mengakibatkan ketidakpusan bagi pekerjaanya (mohd \& che, 2017:3). Berikut ini penelitian tentang kepuasan kerja yang menurun dan banyak terjadi pada perusahaan seluruh dunia, terdapat perusahaan yang memiliki masalah tingkat kepuasan kerja karyawan pada berbagai industri manufakturing maupun jasa. Mulai dari perbankan (Gohari, Kamkar, 2015); (Zaraket, 2017), Mineral dan Energi (Saharuddin \& Sulaiman, 2016), Ritel (Seman \& Suhaimi, 2017); (Chin C. Lye, 2018), Pendidikan (Mustapha \& Zakaria, 2013); (Malik, Danish, \& Munir, 2015), Kaca (Ali \& Zia-ur-rehman, 2014), Hiburan (Lo \& Nessa, 2016). Setiap perusahaan memiliki tingkat kepuasan yang berbeda-beda, hal ini disebabkan karena perbedaan penerapan standar gaji, dan bonus pada karyawan (Srivastav \& Das, 2013).

Kepuasan kerja merupakan hal mendasar yang dirasakan dapat mempengaruhi pemikiran seseorang untuk keluar dari tempatnya bekerja atau turnover (lu \& xiao-min, 2017:2), artinya diperlukan karyawan baru, perusahaan harus mengeluarkan biaya untuk pengrekrutan sampai akhirnya mendapat karyawan yang sesuai dengan kebutuhan (haile \& premanandam, 2017:3).

Ketidakpuasan menyebabkan tingkat trunover salah satunya pada industri manufaktur dan kontruksi yang terjadi pada beberapa negara diseluruh dunia, terdapat perusahaan yang memiliki masalah tingkat kepuasan kerja rendah pada sektor industri bisnis, mulai dari perbankan, industri migas, manufaktur, kontruksi dan sebagainya. Berdasarkan survei yang dilakukan situs Compensation force Permasalahan turnover bidang manufaktur dan ditribusi pada sub bagian engineering atau contruction. Pada tahun 2016 sebanyak 30.000 korporat diseluruh dunia hasilnya menunjukan $16.0 \%$ tingkat turnover (http://www.compensationforce.com/2017/04 /2016-turnover-rates-by industry.html diakses 17/12/2017). Dan terjadi pada Indonesia selama setengah dekade terakhir, pertumbuhan ekonomi semakin tak bertenaga untuk menciptakan lapangan pekerjaan. Saat ini, 1\% pertumbuhan ekonomi hanya mampu menyerap 230.000-250.000 tenaga kerja. Khususnya pada sektor konstruksi juga mengalami penurunan penyerapan tenaga kerja sebesar 229.000 tenaga kerja atau turun $2,8 \%$. Padahal, pemerintah dalam dua tahun terakhir telah menggenjot pembangunan infrastruktur (www. betahita.id diakses 21/01/2018).

Setiap perusahaan memiliki tingkat kepuasan yang berbeda-beda, hal ini disebabkan karena perbedaan penerapan standar gaji, dan bonus pada karyawan (Srivastav \& Das, 2013), dan tuntutan yang diberikan perusahaan terhadap karyawan, tolok ukur tingkat kepuasan yang mutlak tidak ada karena setiap individu karyawan berbeda standar kepuasannya (Khan \& Afzal, 2016), namun jika ketidakpuasan penyebab utama karyawan dibiarkan terlalu lama dan tidak ada kebijakan perusahaan untuk menyelesaikan, perusahaan rela 
kehilangan karyawan yang berharga dan terampil (Lu \& Xiao-min, 2017).

Ketidakpuasan menimbulkan dampak bagi karyawan maupun perusahaan diantaranya dampak terhadap produktivitas, dampak terhadap ketidakpuasan dan keluarnya tenaga kerja (turnover), dampak terhadap kesehatan (Seman \& Suhaimi, 2017) selain itu karyawan akan mengeluh, membangkang, mencuri barang milik perusahaan/organisasi, menghindari sebagian tanggung jawab pekerjaan mereka dan lainnya (Robbins \& Judge, 2013), jika karyawan yang tidak puas akan mengevaluasi diri inti negatif menetapkan tujuan yang kurang ambisius dan cenderung menyerah saat menghadapi kesulitan (Inuwa, 2015). Hal ini merujuk berdasarkan hasil survei pengumpulan data laporan absensi, ketidakhadiran, dan karyawan dan karyawan datang terlambat pada perusahan yang menurun diindikasikan faktor kepuasan kerja yang cukup rendah (Medgyesi \& Zólyomi, 2016).

Mengingat permasalahan kepuasan kerja, maka masalah tersebut dapat atasi dengan pendekatan manajemen sumber daya manusia (MSDM) yang terdapat dalam lima fungsi dasar yaitu: Environment of Human Resource, Jobs and Labor, Talent Development, Compensation dan Employee Relations. Kepuasan kerja karyawan berada pada fungsi job and labor (Mathis. 2017). Berdasarkan beberapa penelitian faktor yang mempengaruhi kepuasan kerja karyawan adalah kunci ingridient yang mengarah pada pengakuan, pendapatan, promosi, dan pencapaian tujuan lain yang mengarah pada perasaan pemenuhan ( $\mathrm{Li} \&$ Roessler, 2017), dan faktor yang dikekemukakan oleh (Kreitner dan Kinicki, 2010; Wibowo, 2014:415) yaitu: pemenuhan kebutuhan (need fulfillment, perbedaan (discrepencis), pencapaian nilai (value attaintment), keadilan (equity), komponen genetik (genetic component).

Solusi yang diambil untuk meningkatkan kepuasan kerja yaitu dengan membuat program promosi jabatan dan penghargaan. Solusi pertama yaitu program promosi jabatan, penelitian yang dilakukan oleh (Saharuddin \& Sulaiman, 2016) menyatakan bahwa program promosi berpengaruh signifikan terhadap kepuasan kerja karyawan, pendapat lain bahwa program promosi jabatan kurang berpengaruh dan signifikan terhadap kepuasan kerja karyawan (Malik et al., 2015). Solusi kedua yaitu penghargaan, dalam penelitian yang dilakukan (Seman \& Suhaimi, 2017) menyatakan bahwa penghargaan mempengaruhi secara signifikan terhadap kepuasan kerja.

Upaya yang dilakukan PT. Gunanusa Utama Fabricators Serang dalam mempertahankan kepuasan kerja yaitu dengan membuat program promosi jabatan dan pemberian penghargaan baik finansial Maupin non finansial kepada karyawan. Strategi yang dilakukan PT. Gunanusa Utama Fabricators Serang yaitu dengan membuat penilaian kinerja yang terstruktur dan transparansi kepada karyawan, adanya sarana olahraga bersama, tempat peristirahatan yang nyaman lingkungan kerja yang nyaman baik di dalam ruangan maupun diluar ruangan. Sehingga harapan dan keinginan karyawan terpenuhi dan meningkatkan kinerja yang baik.

Tujuan penelitian ini adalah untuk mengetahui gambaran program promosi jabatan, penghargaan dan kepuasan kerja.

\section{KAJIAN PUSTAKA}

Dalam membantu penetapan tujuan tersebut perlu adanya bantuan dari fungsi-fungsi manajemen untuk perbaikan kualitas SDM (Rivai \& Ella. 2013:3), Mathis, (2017:1) mengemukakan bahwa fungsi-fungsi manajemen sumber daya manusia terdiri dari beberapa bagian penting yaitu, environment of human resource, jobs and labor, talent development, compensation dan employee relations.

Salah satu langkah penting untuk mempertimbangkan sumber daya manusia yaitu jobs and labor. Terdapat tiga faktor yang secara spesifik mempengaruhi perilaku dan kinerja karyawan, yaitu Terdapat tiga faktor yang secara spesifik mempengaruhi perilaku dan kinerja karyawan, yaitu employee attitudes dan organizational commitment dalam perilaku organisasi dan praktik pengelolaan sumber daya manusia (Luthans, 2015:118). Karyawan termotivasi ketika mengarah pada pencapaian tujuan, perasaaan dihargai, memenuhi kebutuhan dan keinginan karyawan, teori motivasi menyatakan dua aspek dari dampak motivasi yaitu kepuasan kerja dan efek gaji pada motivasi (Armstrong \& Taylor, 2017:167).

Kepuasan kerja menjadi penting karena kehadirannya akan menyebabkan produktivitas yang lebih baik dari sumber daya manusia dan tidak adanya kepuasan kerja menyebabkan penyusutan dari fungsi personil atau karyawan (Prabhakar, 2016:640). Kepuasan kerja dipandang sebagai tingkat orientasi afektif seorang karyawan terhadap peran kerja yang diduduki di institusi tersebut (Mohd \& Che, 2017:1). Pentingnya kepuasan kerja karena meningkatkan produktivitas dan menghasilkan sikap positif terhadap komitmen kerja, yang pada gilirannya mengurangi tingkat ketidakhadiran, pemberhentian pelayanan, kelalaian kerja, produktivitas dan dapat meningkatkan usaha terhadap kinerja kerja dan mental serta kesehatan fisik karyawan (Malik et al., 2015:4).

Kepuasan kerja dapat didefinisikan sebagai sikap dan perasaan orang tentang pekerjaan mereka yang ditunjukkan dengan sikap positif yang 
menguntungkan terhadap pekerjaan, dan sikap negatif yang tidak menguntungkan terhadap pekerjaan menunjukkan ketidakpuasan kerja (Armstrong \& Taylor, 2017:177). Pekerjaan membutuhkan interaksi dengan rekan sekerja dan para atasan, mematuhi peraturan dan kebijakan organisasi, memenuhi standar kinerja, hidup dengan suasana kerja yang sering kali kurang dari ideal (Robbins, 2013:79). Kepuasan kerja merupakan sikap umum individu terhadap pekerjaannya sehingga lebih mencermikan sikap dari pada perilaku (Haile \& Premanandam, 2017:2), keyakinan bahwa karyawan yang puas lebih produktif daripada karyawan yang tidak puas menjadi prinsip dasar bagi para manajer maupun pimpinan (Mehrad, 2016:3).

Kepuasan kerja sebagai melibatkan kognitif, afektif dan evaluatif reaksi atau sikap menyenangkan atau positif secara emosional yang dihasilkan dari penilaian dari seseorang pekerjaan atau pengalaman kerja (Luthans, 2015:212). Selanjutnya menurut (Mondy \& Martocchio, 2016:280) sesuatu yang diterima seseorang dari pekerjaannya baik secara fisik maupun psikologis dimana orang itu bekerja. Pendapat yang serupa oleh (Robbins 2013:74) bahwa kepuasan kerja berbicara tentang sikap karyawan, yang menggambarkan perasaan positif tentang pekerjaan, hasil dari evaluasi karakteristiknya dan kepuasan kerja adalah keadaan emosional positif yang dihasilkan dari penilaian pengalaman kerja seseorang.

Serta pendapat lain yang dikemukaaan oleh (Rivai \& Ella, 2013:856) kepuasaan kerja merupakan evaluasi yang mengagambarkan atas perasaan sikapnya senang atau tidak senang, puas atau tidak puas dalam bekerja.

Berdasarkan beberapa definisi yang telah dikemukakan oleh beberapa ahli dapat ditarik satu kesimpulan bahwa kepuasan kerja karyawan sebagai perasaaan menggambarkan sikap, perasaan, dan emosi seorang karyawan terhadap pekerjaannya.

Kepuasan kerja sering dijadikan ukuran tingkat kematangan suatu organisasi dalam kehidupan organisasi modern. Hal ini berarti bahwa organisasi dikelola dengan baik yang merupakan hasil manajemen yang efektif. Berikut ini terdapat lima dimensi dalam kepuasan kerja (Luthans, 2015:212) mengemukakan terdapat, yaitu: 1) the work itself, 2) pay , 3) promotion opportunitie, 4) supervision, 5) coworkers. Dimensi kepuasan kerja (Robbins, 2013:79) 1). sifat pekerjaan, 2). pengawasan, 3). gaji sekarang, 4). peluang promosi, dan 5). hubungan dengan rekan kerja. Kepuasan kerja terdapat beberapa dimensi (Mathis \& Jackson, 2017:158) terdiri dari 1). worker relationships, 2). pay and benefits, 3). performance recognition, and 4). communications with managers and executives.
Pendapat yang dikemukakan oleh (Ghiseli \& Brown 1950; Mishra, 2013:4) mengemukakan adanya lima faktor yang menimbulkan kepuasan kerja, yaitu :

a. Kedudukan (posisi)

Umumnya manusia beranggapan bahwa seseorang yang bekerja pada pekerjaan yang lebih tinggi akan merasa lebih puas daripada mereka yang bekerja pada pekerjaan yang lebih rendah.

b. Pangkat (golongan)

Pada pekerjaan yang mendasarkan perbedaan tingkat (golongan), sehingga pekerjaan tersebut memberikan kedudukan tertentu pada orang yang melakukannya. Apabila ada kenaikan upah, maka sedikit banyaknya akan dianggap sebagai kenaikan pangkat, dan kebanggaan terhadap kedudukan yang baru itu akan merubah perilaku dan perasaannya.

c. Umur

Dinyatakan bahwa ada hubungan antara kepuasan kerja dengan umur karyawan. Umur di antara 25 tahun sampai 34 tahun dan umur sampai 40 sampai 45 tahun adalah merupakan umur-umur yang bias menimbulkan perasaan kurang puas terhadap pekerjaan.

d. Jaminan finansial dan jaminan sosial

Masalah finansial dan jaminan sosial kebanyakan berpengaruh terhadap kepuasan kerja.

e. Mutu pengawasan

Hubungan antara karyawan dengan pihak pimpinan sangat penting artinya dalam menaikkan produktifitas kerja. Kepuasan karyawan dapat ditingkatkan melalui perhatian dan hubungan yang baik dari pimpinan kepada bawahan, sehingga karyawan akan merasa bahwa dirinya merupakan bagian yang penting dari organisasi kerja.

Berdasarkan gambar diatas terdapat 4 respon terhadap ketidakpuasan kerja karyawan (Robbins \& Judge, 2013:82), yaitu:

1. Exit (keluar) yaitu perilaku yang diarahkan ke arah meninggalkan organisasi, mencakup pencarian suatu posisi baru maupun meminta berhenti.

2. Voice (suara) yaitu perilaku yang dengan aktif dan konstruktif mencoba memperbaiki kondisi. Mencakup saran perbaikan, membahas problem-problem dengan atasan, dan beberapa bentuk kegiatan serikat buruh.

3. Loyalty (kesetiaan) yaitu perilaku yang pasif tetapi optimis menunggu kondisi membaik, mencakup berbicara membela organisasi menghadapi kritik luar dan mempercayai organisasi dan manajemennya untuk "melakukan hal yang tepat". 
4. Neglect (pengabaian) yaitu secara pasif membiarkan kondisi memburuk, termasuk kemangkiran atau datang terlambat secara kronis, upaya yang dikurangi, dan tingkat kekeliruan yang meningkat.

Berdasarkan penjelasan oleh para ahli mengenai dimensi kepuasan kerja, maka peneliti menggunakan (Luthans, 2015:212). Kepuasan kerja dapat ditingkatkan oleh perusahaan dengan prosedur yang benar, sehingga karyawan merasa dihargai atas kinerjanya.

Teori lain yang serupa mengenai kepuasan kerja yang cukup dikenal (Rivai \& Ella, 2013:856) adalah:

1) Teori Ketidaksesuaian (Discrepancy Theory). Teori ini mengukur kepuasan kerja seseorang dengan menghitung selisih antara sesuatu yang seharusnya dengan kenyataan yang dirasakan.

2) Teori Keadilan (Equity Theory). Teori ini mengemukakan bahwa orang akan merasa puas atau tidak puas, tergantung pada ada atau tidaknya keadilan (equity) dalam suatu situasi, seperti pendidikan, pengalaman, kecakapan, jumlah tugas dan peralatan atau perlengkapan yang dipergunakan untuk melaksanakan pekerjaannya.

3) Teori dua faktor (Two factor theory). Teori ini merumuskan karakteristik pekerjaan menjadi dua kelompok yaitu satisfies atau motivator dan dissatisfies. Satisfies ialah faktor-faktor atau situasi yang dibutuhkan sebagai sumber kepuasan kerja yang terdiri dari: pekerjaan yang menarik, penuh tantangan, ada kesempatan untuk berprestasi, kesempatan memperoleh penghargaan dan promosi, terpenuhinya faktor tersebut akan menimbulkan kepuasan, namun tidak terpenuhinya faktor ini tidak selalu mengakibatkan ketidakpuasan. Dissatisfies (hygiene factors) adalah faktor-faktor yang menjadi sumber ketidakpuasan, yang terdiri dari: gaji/upah, pengawasan, hubungan antarpribadi, kondisi kerja dan status

Selanjutnya program promosi jabatan merupakan salah satu bagian dari program penempatan yang dilaksanakan oleh perusahaan. penempatan karyawan dilakukan dengan membuat penyesuaian terhadap kebutuhan perusahaan yang berhubungan dengan perencanaan untuk memperoleh orang yang tepat pada posisi yang tepat (simanjuntak yulyarta, 2015:5), secara tradisional merujuk pada kemajuaan ke posisi dengan tanggung jawab yang lebih besar (Dessler 2015:385), promosi dimana kenaikan gaji dan status secara langsung ke arah yang lebih tinggi pada perusahaan (Noe, 2010:452).

Pendapat lain bahwa promosi adalah kebijakan untuk karyawan mengisi kekosongan posisi pada level lebih tinggi dalam perusahaan (mondy \& martocchio, 2016:148), karyawan yang dipromosikan oleh perusahaan dipindahkan dari satu pekerjaan ke pekerjaan lain yang lebih tinggi dalam pembayaran, tanggung jawab, dan atau level (rivai \& ella, 2013:199). Kenaikan jabatan atau promosi mempunyai nilai sendiri karena merupakan bukti pengukuhan terhadap prestasinya sehingga dengan promosi jabatan bagi pegawai yang mempunyai prestasi yang tinggi, akan dapat ditingkatkan jabatannya sesuai dengan kemampuannya (saharuddin \& sulaiman, 2016:5).

Berdasarkan beberapa definisi yang telah dikemukakan oleh beberapa ahli dapat ditarik satu kesimpulan bahwa promosi adalah dialokasikan untuk pekerja yang memiliki kriteria tertentu untuk perpindahan pekerjaan seseorang dari satu jabatan kejabatan yang lebih tinggi, wewenang dan tanggung jawab semakin besar, status serta pendapatan juga semakin tinggi selama periode tertentu. Maka kajian peneliti terhadap program promosi jabatan mengacu pada definisi yang dikemukakan oleh (Mondy \& Martocchio, 2016:148).

Melihat besarnya peranan promosi jabatan bagi kehidupan sekaligus kelangsungan karier karyawan di perusahaan, maka para karyawan berlomba untuk dapat bersaing dalam mengisi jabatan yang akan dipromosikan, untuk melaksanakan promosi, maka harus dapat ditetapkan syarat-syarat yang jelas terlebih dahulu (Azka, Albakir, \& Hidayat, 2016:1). Kriteria yang harus dipenuhi untuk melakukan kebijakan promosi jabatan (Dessler 2015:386). yaitu 1). masa jabatan, 2). nilai kinerja. Serta karyawan yang akan dipromosikan kan dilihat beberapa kriteria (Mondy \& Martocchio, 2016:148) yaitu: 1). work performance, 2). personal quality, 3). track record, 4). new ideas dan Innovations. Selanjutnya keberhasilan karir seseorang dipengaruhi oleh beberapa dimensi (Kal, 2007:74; Zaheer, Rehman, 2013:3) yaitu: 1). pendidikan formal. 2). pengalaman kerja. 3). sikap atasan. 4). prestasi kerja. 5). adanya lowongan jabatan dan 6). produktivitas kerja.

Berdasarkan penjelasan oleh para ahli mengenai kriteria promosi jabatan, maka peneliti menggunakan (Mondy \& Martocchio, 2016:148). Kriteria promosi tersebut harus dapat dipakai untuk menetapkan siapa yang berhak untuk segera dipromosikan, untuk itu hendaknya syarat-syarat yang ditetapkan dapat menjamin bahwa karyawan yang akan dipromosikan mempunyai kemampuan untuk menjabat jabatan yang lebih tinggi (Alshaibah \& Habtoor, 2015:5).

Berikut ini adalah dasar- dasar promosi jabatan yang diikemukaan oleh (Dessler, 2013:338), antara lain : 
1. Promosi berdasarkan prestasi kerja

Promosi ini menggunakan hasil penilaian prestasi kerja sebagai dasar pengambilan keputusan. Biasanya promosi yang berdasarkan prestasi kerja dilaksanakan oleh organisasiorganisasi yang sudah mapan yang memang sistem prestasi kerjan pegawainya sudah teratur.

2. Promosi berdasarkan senioritas

Promosi ini berarti pegawai yang memiliki masa kerja paling lama adalah orang yang berhak dipromosikan. Adapun alasan organisasi melaksanakan promosi berdasarkan senioritas yaitu selain sebagai penghargaan atas jasa dan loyalitas pegawai yang bersangkutan juga ada anggapan bahwa pegawai senior memiliki pengalaman yang lebih baik

3. Promosi berdasarkan prestasi dan senioritas

Kombinasi prestasi kerja dan senioritas dipandang paling tepat diterapkan dalam organisasi, karena orang yang dipromosikan selain memiliki pengalaman yang lebih banyak juga memiliki prestasi kerja yang tidak mengecawakan.

Selanjutnya penghargaan terdiri dari organisasi terpadu kebijakan, proses dan praktek untuk menghadiahi karyawan sesuai dengan kontribusi mereka, keterampilan dan kompetensi dan peluang pekerjaan (Armstrong, 2014:362), dalam setiap organisasi harus diarahkan untuk mendorong produktivitas. Penghargaan diberikan kepada karyawan yang memiliki kompetensi dan kemampuan yang melebihi standar untuk mencapai tujuan perusahaan sehingga karyawan akan termotivasi untuk tetap dalam pekerjaannya (Dessler 2013:275).

Penghargaan yang diberikan kepada karyawan yang dirancang dan dikelola, dan sangat penting untuk menarik, mempertahankan dan mencapai hasil yang diinginkan (Wilkinson, Redman, 2017:159), pengakuan atas suatu prestasi, akan memberikan kepuasan yang lebih tinggi dari pada penghargaan dalam bentuk materi atau hadiah, penghargaan mencakup nilai dan hubungan yang karyawan rasakan (Mondy, \& Martocchio, 2016:280).

Definisi di atas dapat ditarik satu kesimpulan bahwa penghargaan adalah imbalan balas jasa yang diberikan oleh perusahaan atas kontribusi karyawan imbalan yang diberikan baik dalam dalam bentuk material dan non material yang diberikan oleh pihak perusahaan kepada karyawannya. Maka kajian peneliti terhadap program promosi jabatan mengacu pada definisi yang dikemukakan oleh (Wilkinson, Redman, 2017:159).

Penghargaan merupakan suatu cara untuk meningkatkan produktivitas kerja karyawan dan perilaku seseorang sehingga dapat mempercepat pelaksanaan pekerjaan yang dibebankan dan pada akhirnya target atau tujuan yang ingin dicapai dapat terlaksana dengan baik. Dimensi yang dikemukakan oleh (Luthans, 2015:90), yaitu: 1). salary, 2). bonuses, 3). incentive pay), 4.) recognition, and 5). benefits.

Armstrong, (2014:364) meliputi: penghargaan finansial: 1). base pay, 2). contingent pay, 3). employee benefits, 4). pensions, dan penghargaan non finansial: 1). recognition, 2). job design, 3). opportunity to develop, 5). work environment. Dimensi serupa yang dikemukakan (Mathis Jackson 2017:118) oleh 1). base pay (wage or a salary), 2). variable pay, dan 3). benefit. Dimensi

yang dikemukakan oleh

\section{$\&$}

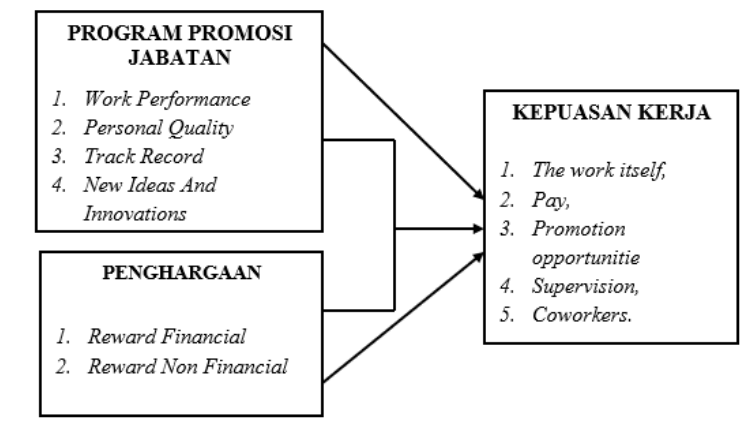

(Wilkinson et al. 2017:162), dalam teorinya, yaitu:

1) Penghargaan finansial: salary, merit pay, bonuses, dan benefits

2) Penghargaan non finansial: job security, recognition, status, training opportunities.

Mengenai dimensi penghargaan, maka peneliti menggunakan (Wilkinson et al. 2017:162). Karena pemberian promosi jabatan akan meningkatkan seorang karyawan ke posisi yang lebih tinggi dibandingkan mereka yang tidak mendapatkan kesempatan promosi tersebut.

Besar kecilnya penghargaan yang diberikan kepada yang berhak bergantung kepada banyak hal, terutama ditentukan oleh tingkat pencapaian yang diraih. Selain itu bentuk penghargaan ditentukan pula oleh jenis atau wujud pencapaian yang diraih serta kepada siapa reward tersebut diberikan. Terdapat empat faktor yang harus dijadikan dasar dalam mempertimbangkan kebijakan penghargaan (reward) menurut (Nawawi, 1999; Adolfina, 2017:4), yaitu:

1. Konsistensi Internal yang kadang-kadang disebut dengan keadilan internal merujuk kepada pekerjaan atau tingkat keahlian didalam sebuah perusahaan, yang membandingkan kontribusi mereka dalam pencapaian tujuan organisasi.

2. Kompetensi eksternal adalah penetapan besarnya penghargaan pada tingkatan dimana perusahaan masih memiliki keunggulan kompetitif dengan perusahaan lain sehingga perusahaan dapat mempertahankan karyawan 
yang memiliki keunggulan/berkualitas untuk tetap bekerja diperusahaan.

3. Kontribusi karyawan merupakan penetapan besarnya penghargaan yang merujuk kepada kontribusi yang telah diberikan karyawan kepada perusahaan. Penghargaan dapat ditetapkan berdasarkan senioritas, prestasi kerja, panduan insentif, dan program yang ada di dalam perusahaan.

4. Administrasi merupakan faktor keempat yang dijadikan bahan petimbangan oleh perusahaan dalam menetapkan kebijaksanaan pemberian penghargaan, antara lain aspek perencanaan, anggaran yang tersedia, komunikasi dan evaluasi.

Berdasarkan penjelasan mengenai pengaruh kepuasan kerja dan penghargaan terhadap kepuasan kerja maka disusun sebuah paradigma pengaruh karakteristik pekerjaan terhadap kepuasan kerja serta implikasinya terhadap kinerja karyawan secara jelas digambarkan dalam Gambar 1.1 sebagai berikut:

\section{Paradigma Pemikiran Gambar 1.1}

\section{METODE PENELITIAN}

Penelitian ini dilakukan untuk mengetahui gambaran program promosi jabatan, penghargaan, danvkepuasan kerja. Variabel bebas yang terdapat pada penelitian ini yaitu program promosi jabatan dengan dimensi 1). work performance (kinerja kerja), 2). personal quality (kualitas pribadi), 3). track record (rekam jejak), 4). new ideas \&Innovations (ide baru \& inovatif). Serta varibel penghargaan 1). Salary (gaji), 2). merit pay (pembayaran mert), 3). Bonuses (bonus), 4). Benefits (manfaat), 5). job security (keamanan kerja), 6). Recognition (pengakuan), 7). status, 8). training opportunities (peluang pelatihan). Sedangkan variabel terikat yaitu kepuasan kerja dengan dimensi 1) the work itself (pekerjaan itu sendiri) , 2) pay (pembayaran), 3) promotion opportunitie (peluang promosi), 4) supervision (supervisi), 5) coworkers (rekan kerja).

Objek/unit analisis pada penelitian ini adalah pada PT. Gunanusa Utama Fabricators Serang. Penelitian ini akan dilakukan pada kurun waktu kurang dari satu tahun di tahun 2018, maka metode penelitian yang digunakan adalah cross sectional method dengan cara mempelajari objek dalam satu kurun waktu tertentu atau tidak berkesinambungan salam jangka waktu panjang. maka metode yang digunakan dalam penelitian ini adalah metode survey explanatory (Malhotra, 2010:96).

Metode penelitian yang digunakan dalam penelitian ini adalah penelitian deskriptif. Tujuan dari penelitian deskriptif adalah membuat deskripsi, gambaran atau lukisan secara sistematis, faktual dan akurat, mengatasi fakta-fakta, sifat-sifat, serta hubungan antara fenomena yang diselidiki. Maksud dari penggunaan metode penelitian deskriptif dalam penelitian ini adalah untuk mengetahui gambaran secara keseluruhan mengenai pengaruh program promosi jabatan dan penghargaan terhadap kepuasan kerja karyawan dengan menggunakan distribusi frekuensi.

Teknik yang digunakan dalam penelitian ini adalah teknik Sampel Random Sampling. Peneliti dalam memilih sampel dengan memberikan kesempatan yang sama kepada semua anggota populasi untuk ditetapkan sebagai anggota sampel. Dengan teknik tersebut terpilihnya individu menjadi anggota sampel benar-benar atas dasar faktor kesempatan (chance), dalam arti memiliki kesempatan yang sama, bukan karena adanya pertimbangan subjektif dari peneliti. Selanjutnya populasi karyawan sebanyak 705 karyawan, dengan pengambilan jumlah sampel menggunakan rumus Slovin Sugiyono, (2013:11) menjadi 90 karyawan. Sumber data penelitian adalah sumber data yang diperlukan untuk penelitian baik yang diperoleh secara langsung kepada pengumpul data. Diantaranya:

1. Data primer yaitu data yang dibuat oleh peneliti untuk maksud khusus menyelesaikan permasalahan yang sedang ditangani. Dalam penelitian ini yang menjadi sumber data adalah kuesioner yang disebarkan kepada unit sampel data penelitian.

2. Data sekunder yaitu data yang telah dikumpulkan untuk maksud selain untuk menyelsaikan masalah yang sedang dihadapi. Dalam penelitian ini yang menjadi sumber data sekunder adalah dokumentasi objek penelitian, literatur, artikel, jurnal serta studi internet yang berkenaan dengan penelitian yang dilakukan. 
Secara lebih jelasnya mengenai data primer dan data sekunder yang digunakan dalam penelitian ini dapat dilihat pada Tabel 1.1 berikut ini:

\section{Jenis Dan Sumber Data}

\begin{tabular}{|c|c|c|c|}
\hline No & Data Penelitian & Sumber Data & Jenis Data \\
\hline 1 & Program Promosi Jabatan & $\begin{array}{l}\text { Kuisioner karyawan PT. } \\
\text { Gunanusa Utama } \\
\text { Fabricators }\end{array}$ & Primer \\
\hline 2 & Penghargaan & $\begin{array}{l}\text { Kuisioner karyawan PT. } \\
\text { Gunanusa Utama } \\
\text { Fabricators }\end{array}$ & Primer \\
\hline 3 & Kepuasan Kerja & $\begin{array}{l}\text { Kuisioner karyawan PT. } \\
\text { Gunanusa Utama } \\
\text { Fabricators }\end{array}$ & Primer \\
\hline 4 & $\begin{array}{l}\text { Profil PT. Gunanusa } \\
\text { Utama Fabricators }\end{array}$ & $\begin{array}{l}\text { PT. Gunanusa Utama } \\
\text { Fabricators }\end{array}$ & Sekunder \\
\hline 5 & $\begin{array}{l}\text { Turnover karyawan PT. } \\
\text { Gunanusa Utama } \\
\text { Fabricators }\end{array}$ & $\begin{array}{l}\text { PT. Gunanusa Utama } \\
\text { Fabricators }\end{array}$ & Sekunder \\
\hline 6 & $\begin{array}{l}\text { Rekapitulasi } \\
\text { ketidakhadiran karyawan } \\
\text { PT. Gunanusa Utama } \\
\text { Fabricators }\end{array}$ & $\begin{array}{l}\text { PT. Gunanusa Utama } \\
\text { Fabricators }\end{array}$ & Sekunder \\
\hline 7 & $\begin{array}{l}\text { Rekapitulasi } \\
\text { keterlambatan karyawan } \\
\text { dan Pulang Cepat PT. } \\
\text { Gunanusa Utama } \\
\text { Fabricators }\end{array}$ & $\begin{array}{l}\text { PT. Gunanusa Utama } \\
\text { Fabricators }\end{array}$ & Sekunder \\
\hline
\end{tabular}

Tabel 1.1

\section{HASIL PENELITIAN DAN PEMBAHASAN}

Gambaran Program Promosi Jabatan

\begin{tabular}{llccc}
\hline No. & \multicolumn{1}{c}{ Dimensi } & $\begin{array}{l}\text { Total } \\
\text { Skor }\end{array}$ & $\begin{array}{c}\text { Skor } \\
\text { Ideal }\end{array}$ & \% \\
\hline 1 & $\begin{array}{l}\text { Work } \\
\text { Performance }\end{array}$ & 2316 & 3150 & 73,52 \\
2 & $\begin{array}{l}\text { Personal } \\
\text { Quality }\end{array}$ & 1827 & 2520 & 72.5 \\
3 & $\begin{array}{l}\text { Track Record } \\
4\end{array}$ & 1402 & 1890 & 74,17 \\
& $\begin{array}{l}\text { New Ideas dan } \\
\text { Innovations }\end{array}$ & 1851 & 2520 & 73,45 \\
\hline & Total Skor & $\mathbf{7 3 9 6}$ & $\mathbf{1 0 0 8 0}$ & $\mathbf{7 3 , 3 7}$ \\
\hline
\end{tabular}

Rekapitulasi Variabel Program Promosi Jabatan Tabel 1. 2

Berdasarkan Tabel 1.2 aspek program promosi jabatan paling tinggi yaitu terdapat pada dimensi work performance (kinerja kerja) memperoleh skor sebanyak 2316 atau 73,52\%, sementara dimensi paling rendah yaitu pada track record (rekam jejak) memperoleh skor 1402 atau $74,17 \%$. Secara keseluruhan variabel program promosi jabatan memperoleh skor 7396, apabila di persentasekan kedalam skor ideal maka diperoleh persentase sebesar $73,37 \%$.

Terdapat pada dimensi work performance (kinerja kerja) memperoleh skor tertinggi sebanyak 2316 atau 73,52\%, Performance diartikan sebegai kinerja, hasil kerja atau prestasi kerja, kinerja adalah melakukan pekerjaan dan hasil yang dicapai dengan pakerjaan tersebut (Wibowo, 2014:2), dimana kinerja mangacu pada tingkat keberhasilan seseorang secara keseluruhan selama periode tertentu di dalam melaksanakan tugas dibandingkan dengan berbagai kemungkinan, seperti standar hasil kerja, target atau sasaran atau kriteria yang telah ditentukan terlebih dahulu dan disepakati bersama. kaitannya dengan hasil pekerjaan seseorang dalam suatu organisasi. Tugas yang dilaksanakan mengacu pada tugas-tugas yang diperintahkan atau dinyatakan sebagai tanggung jawab yang dipercayakan dalam jabatannya. Karyawan memiliki ketepatan dalam menjalankan tugas sesuai dengan pekerjaan, memiliki ketelitian dalam menjalankan tugas sesuai dengan pekerjaan, dalam memeriksa kembali pekerjaan yang telah diselesaikan (Bernardin \& Russel, 2003; Svendsen \& Unterrainer, 2018).

Sementara dimensi paling rendah yaitu pada track record (rekam jejak) memperoleh skor 1402 atau 74,17\%. D Dalam memilih karyawan yang berkinerja baik dapat dilihat dari track record I rekam jejaknya Mondy \& Martocchio, 2016:148), track record adalah hal-hal yang dilakukan seseorang atau sesuatu telah dilakukan atau yang dicapai di masa lalu terutama dianggap sebagai cara untuk menilai apa yang mungkin dilakukan orang atau benda di masa depan (Balu dan Meyer 1981:155;Svendsen \& Unterrainer, 2018). Rekam jejak menjadi tolak ukur untuk karyawan dalam menaikan panngkat atau jabatan di perusahaan. Perusahan tidak menerima karyawan yang memiliki rekam jejak buruk seperti tidak tepat waktu, menurunya kinerja, tidak komitmen dan berperilaku buruk, karyawan buruk yang hanya akan mendatangkan kerugian di masa depan karena reputasi buruk yang dihasilkannya. Sebaliknya perusahaan akan menerima karyawan yang memiliki rekam jejak yang baik, terutama pada hasil kerja yang memuaskan dan kemajuan perusahaan akan cepat tercapai. Perlunya penelusuran rekam jejak di gunakan untuk bahan penilaian (Grille, Schulte, \& Kauffeld, 2015:6).

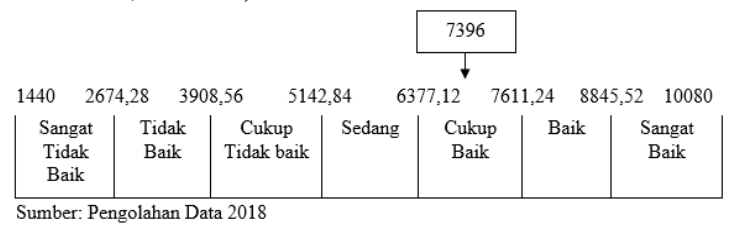

Skor ideal program promosi jabatan adalah 10080 untuk 16 item pernyataan. Perolehan skor berdasarkan hasil pengolahan dari variabel program promosi jabatan adalah 7396 atau 73,37\%, skor tersebut secara kontinum dapat digambarkan sebagai berikut:

\section{Hasil Kontinum Variabel Program Promosi Jabatan \\ Gambar 1.2}

Berdasarkan Gambar 1.2 pada nilai kontinum variabel program promosi jabatan yaitu 
7396 sesuai dengan data penelitian yaitu termasuk kedalam kategori cukup baik. yaitu pada interval 6377,12 - 7611,24. Dengan demikian dapat dikatakan bahwa perusahaan telah menerapkan program promosi jabatan yang cukup baik, namun masih perlu ditingkatkan lagi karena semua dimensi masih berada dibawah skor ideal.

\section{Gambaran Penghargaan}

\begin{tabular}{llccc}
\hline \multirow{2}{*}{ No. } & \multicolumn{1}{c}{ Dimensi } & $\begin{array}{r}\text { Total } \\
\text { Skor }\end{array}$ & $\begin{array}{c}\text { Skor } \\
\text { Ideal }\end{array}$ & \% \\
\hline 1 & Salary & 1802 & 2520 & 73,97 \\
2 & Merit pay & 1340 & 1890 & 70,89 \\
3 & Bonuses & 1421 & 1890 & 75,18 \\
4 & Benefit & 1823 & 2520 & 72,34 \\
5 & Job Security & 1391 & 1890 & 73,59 \\
6 & Recognition & 1438 & 1890 & 76,08 \\
7 & Status & 1438 & 1890 & 76,08 \\
8 & Training & 1459 & 1890 & 77,19 \\
& Opportunities & & & $\mathbf{7 3 , 9 8}$ \\
\hline & Total Skor & $\mathbf{1 2 1 1 8}$ & $\mathbf{1 6 3 8 0}$ & $\mathbf{7}$
\end{tabular}

\section{Rekapitulasi Variabel Penghargaan} Tabel 1.3

Berdasarkan Tabel 1.3 aspek penghargaan paling tinggi yaitu terdapat pada dimensi benefit (manfaat) memperoleh skor sebanyak 1829 atau $72,34 \%$, sementara dimensi paling rendah yaitu pada job security memperoleh skor 1340 atau $73,59 \%$. Secara keseluruhan penghargaan memperoleh skor 12118 apabila di persentasekan kedalam skor ideal maka diperoleh persentase sebesar $73,98 \%$.

Terdapat pada dimensi benefit (manfaat) memperoleh skor sebanyak 1829 atau 72,34\%. Perlunya asuransi tidak hanya didapatkan untuk manfaat secara finansial saja melainkan juga manfaat psikologis bagi pekerja itu sendiri. Memiliki sebuah asuransi atau lebih berarti memiliki rencana cadangan apabila terjadi suatu. satu hal yang dapat meminimalisir resiko tersebut adalah dengan asuransi, asuransi menguntungkan kehidupan masyarakat dengan mengurangi kekayaan yang harus disisihkan untuk menutupi kerugian akibat berbagai resiko yang didapat. Cara perusahaan untuk menawarkan manfaat adalah untuk menarik dan mempertahankan bakat dan memenuhi tanggung jawab kepada karyawan. Perusahaan menyediakan berbagai perawatan kesehatan dan manfaat medis (Mathis, 2011:451), masing-masing menyediakan dan memenuhi kebutuhan sekelompok karyawan tertentu. Dimana terdapat asuransi jiwa tambahan, asuransi cacat, dan cakupan kesehatan (Robbins \& Judge, 2013:259), banyaknya undangn-undang mengenai pemberian asuransi kerja kepada karyawan, adalah untuk membuat kesehatan jiwa yang berkelanjutan bagi karyawan (Mondy, R. W., \& Martocchio, 2016:292).

Sementara dimensi paling rendah yaitu pada job security memperoleh skor 1340 atau $73,59 \%$. Keamanan mengacu pada kondisi di mana kesejahteraan fisik orang dilindungi, tujuan utama dari program keselamatan yang efektif dalam organisasi adalah untuk mencegah kecelakaan dan kecelakaan yang berkaitan dengan pekerjaan serta melindungi karyawan dan bertujuan untuk menjamin keadaan,keutuhan dan kesempurnaan tenaga kerja (baik jasmaniah maupun rohaniah) beserta hasil karya dan alat-alat kerjanya ditempat kerja. Dengan pertumbuhan kekerasan di tempat kerja dan masalah manajemen risiko lainnya, keamanan telah menjadi perhatian yang lebih besar bagi pengusaha dan karyawan (Mathis, 2011:451:470).

Skor ideal penghargaan adalah 16380 untuk 26 item pernyataan. Perolehan skor berdasarkan hasil pengolahan data pada variabel penghargaan adalah 12118, skor tersebut secara kontinum dapat digambarkan sebagai berikut:

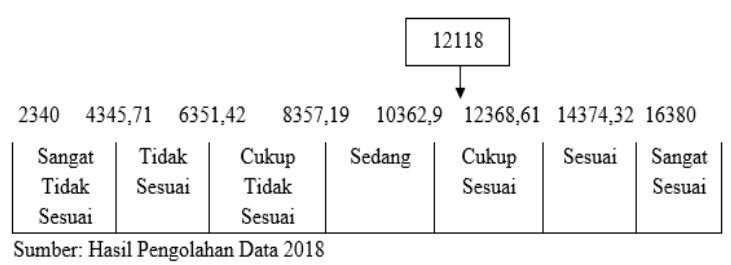

Gambar 1.3

Hasil Kontinum Variabel Program Promosi Jabatan

Berdasarkan Gambar 1.3 pada nilai kontinum variabel penghargaan yaitu 12118 sesuai dengan data penelitian yaitu termasuk kedalam kategori cukup sesuai yaitu pada interval 10362,912368,61. Dengan demikian dapat dikatakan bahwa perusahaan telah menerapkan penghargaan cukup sesuai. Namun masih perlu ditingkatkan lagi karena semua dimensi masih berada dibawah skor ideal.

Gambaran Kepuasan Kerja

\begin{tabular}{|c|c|c|c|c|}
\hline No. & Dimensi & $\begin{array}{l}\text { Total } \\
\text { Skor }\end{array}$ & $\begin{array}{l}\text { Skor } \\
\text { Ideal }\end{array}$ & $\%$ \\
\hline 1. & The work itself & 1757 & 2100 & $83 \%$ \\
\hline 2. & Pay & 1809 & 2100 & $86 \%$ \\
\hline 3. & $\begin{array}{l}\text { Promotion } \\
\text { Opportunities }\end{array}$ & 2418 & 3150 & 76,76 \\
\hline 4. & Supervision & 3292 & 4263 & 77,22 \\
\hline
\end{tabular}




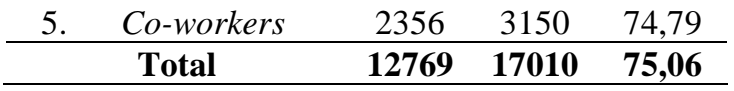

Tabel 1.4

\section{Rekapitulasi Variabel Kepuasan Kerja}

Berdasarkan Tabel 1.3 aspek kepuasan kerja paling tinggi yaitu terdapat pada dimensi Supervision (supervisi) memperoleh skor sebanyak 3292 atau 77,22\%, sementara dimensi paling rendah yaitu pada the the work itself (pekerjaan itu sendiri) memperoleh skor 2334 atau 74,09\%. Secara keseluruhan variabel kepuasan kerja memperoleh skor 12769 , apabila di persentasekan kedalam skor ideal maka diperoleh persentase sebesar 75,06\%.

Terdapat pada dimensi Supervision (supervisi) memperoleh skor sebanyak 3292 atau 77,22\%. Di samping itu, pekerja mengharapkan atasan yang disukai tergantung pada apakah atasan mempunyai kepribadian baik, demikian pula apakah mempunyai nilai-nilai dan keyakinan yang sama dengan pekerja (Colquitt, LePine, \& Wesson,2017:68). Supervisi membantu tugas-tugas yang harus diselesaikan kepada karyawan lain. Hal ini dilakukan agar pekerjaan yang banyak dapat diselesaikan dengan secepat mungkin. Cara inipun membuka peluang bagi kepada karyawan untuk dapat mengembangkan kompetensinya dalam bekerja karena diberikan kepercayaan dan wewenang untuk menyelesaikan tugas-tugas yang didelegasikan kepadanya. menyatakan bahwa kemampuan supervisi dalam memberikan bantuan secara teknis maupun dalam memberikan dukungan kepada karyawannya (Luthans, 2015:212).

Sementara dimensi paling rendah yaitu pada the the work itself (pekerjaan itu sendiri) memperoleh skor 2334 atau 74,09\%. The work itself (Pekerjaan itu sendiri) mencerminkan perasaan pekerja tentang tugas pekerjaan mereka sebenarnya, termasuk apabila tugasnya menantang, menarik, dihormati, dan memanfaatkan keterampilan yang dimiliki pekerja merupakan hal penting daripada sifat pekerjaan yang menjemukan, berulang dan tidak nyaman (Colquitt, LePine, \& Wesson, 2017:68). selain itu pekerjaan yang didapatkan karyawan meliputi variasi tugas, kesempatan belajar, kesulitan kerja, jumlah kerja, kesempoatan untuk berhasil, control terhadap langkah-langkah pekerjaan dan metode pekerjaan (Gibson \& Konopaske (2012:102).Jika seseorang karyawan memiliki tingkat kepuasan yang tinggi terhadap pekerjaannya, maka karyawan tersebut akan memiliki produktivitas kerja yang baik. Sebaliknya jika karyawan memiliki tingkat kepuasan yang rendah terhadap pekerjaannya.

Skor ideal kepuasan kerja adalah 17010 untuk 27 item pernyataan. Perolehan skor berdasarkan hasil pengolahan dari variabel kepuasan kerja adalah 12769 atau 75,06\%, skor tersebut secara kontinum dapat digambarkan sebagai berikut:

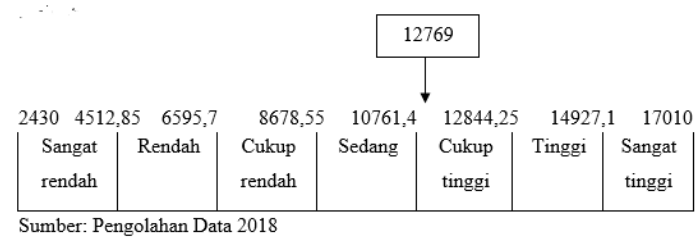

\section{Hasil Kontinum Variabel Program Promosi Jabatan \\ Gambar 1. 4}

Berdasarkan Gambar 1.4 pada nilai kontinum variabel kepuasan kerja yaitu 12769 sesuai dengan data penelitian yaitu termasuk kedalam kategori cukup tinggi yaitu pada interval 10761,4-12844,25. Dengan demikian dapat dikatakan bahwa perusahaan telah menerapkan kepuasan kerja yang cukup tinggi, namun masih perlu ditingkatkan lagi karena semua dimensi masih berada dibawah skor ideal.

\section{KESIMPULAN DAN REKOMENDASI}

Berdasarkan hasil penelitian yang telah dilakukan menggunakan analisis deskriptif dengan distribusi frekuensi dapat diambil kesimpulan yaitu, hasil penelitian menyatakan bahwa program promosi jabatan berada dalam kategori cukup baik, dimensi work performance merupakan dimensi yang memiliki penilaian yang paling tinggi, sementara dimensi yang memiliki penilaian paling rendah track record.

Serta penghargaan kategori cukup sesuai, dimensi benefit merupakan dimensi yang memiliki penilaian yang paling tinggi, sementara dimensi yang memiliki penilaian paling rendah adalah merit pa. Dan kepuasan kerja dalam kategori cukup tinggi, Dimensi supervision merupakan dimensi yang memiliki penilaian paling tinggi dalam kepuasan kerja, sementara dimensi yang memperoleh skor terendah terdapat pada the work itself.

Adanya penelitian ini diharapkan dapat membantu peneliti berikutnya dalam melakukan penelitian mengenai program promosi jabatan, penghargaan dan kepuasan kerja dengan menggunkan indikator yang berbeda dari sumber teori yang lebih beragam, dan terhadap objek yang berbeda, karena masih banyaknya keterbatasan dalam penelitian ini, khususnya yang berkaitan dengan metode penelitian dan teknik pengumpulan data.

Dapat dikatakan bahwa dalam penelitian ini sistem kepuasan kerja yang dimiliki oleh PT. Gunanusa Utama Fabricators Serang telah diaplikasikan dengan cukup tinggi, namun kepuasan kerja perlu ditingkatkan lagi karena semua dimensi berada dibawah skor ideal.Adapun saran-saran 
sebagai masukan untuk perbaikan kepuasan kerja sebagai berikut:

a. Perusahaan harus menyampaikan bahwa program promosi jabatan berlaku untuk semua karyawan untuk menduduki posisi yang kosong. Selanjutnya perusahaan perlunya memberikan informasi tentang syarat-syarat karyawan yang dapat di promosikan di dalam perusahaan, sehingga program promosi dapat di informasikan secara terbuka karena hal ini dapat menjadi motivasi bagi setiap karyawan untuk bekerja dengan sungguh-sungguh dan karyawan mampu mempersiapkan diri dalam mengikuti program promosi tersebut. Serta adanya pengawasan harus memperhatikan dan mendorong kemungkinan adanya umpan balik (feed back) apa pun yang menjadi rekomendasi penilaian.

b. Serta perusahaan memberikan pelayanan yang terbaik untuk karyawanya, jika harapan dan keinginan karyawan terpenuhi maka karyawan akan puas dan kinerja tercapai dengan maksimal. Oleh karena itu perusahaan memberikan penghargaan dengan banyak mempertimbangkan kebutuhan para karyawanya.

\section{DAFTAR PUSTAKA}

Armstrong, M., \& Taylor, S. (2017). Armstrong's Handbook Of Human Resource Management Practice (Fourteenth). London: KoganPage.

Colquitt, J., LePine, J. A., \& Wesson, M. J. (2017). Organizational behavior: Improving performance and commitment in the workplace. New York: McGraw-Hill Irwin.

Dessler, G. (2014). Pearson New International Edition Fundamentals of Human Resource Management (3th ed.). United States of America: Pearson.

Gibson, J. L., John M, I., James H Donelly, J., \& Konopaske, R. (2012). Organizational Behaviour (Thirtheen). South-Western: Cengage Learning.

Luthans. (2011). Organizational Behavior an Evidence Based Approach 12th Edition. Organizational behavior: an edivence-based approach (12th ed.). McGraw-Hill/Irwin.

Luthans, F. (2015). Organizational Behavior (12th Editi). New York: The Mcgrow-Hill Companies Inc.

Mondy, R. W., \& Martocchio, J. J. (2016). Human Resource Management (14th ed.). United States of America: Pearson.
Noe. (2010). Employee Training and Development. (J. Beck, Ed.) (5th ed.). Paul Ducham.

Malhotra, N. K. (2010). Marketing Research an Applied Orientation. New Jersey: Pearson.

Mathis. (2011). Human Resource Management. (13th ed.). South-Western Cengage Learning.

Robbins \& Judge. (2013). Organizational Behavior. (S. Yagan, Ed.) (15th ed.). Pearson.

Wilkinson, A., Redman, T., \& Dundon, T. (2017). Contemporary Human Resource Management. United Kingdom: Pearson.

\section{Jurnal}

Adolfina. (2017). Pengaruh Promosi Jabatan dan Mutasi terhadap prestasi kerja pegawai PT. Bank Mandiri (Persero) Cabang Ahmad Yani Medan, 5(2), 404-413.

Al-shaibah, M., \& Habtoor, N. (2015). Reward System and Job Satisfaction: A Conceptual Review. Reward System and Job Satisfaction: A Conceptual Review, 4(4), 137-141.

Ali, N., \& Zia-ur-rehman, M. (2014). Impact of job design on employee performance, mediating role of job satisfaction : A study of FMCG' $s$ sector in pakistan. International Journal of Business and Management, 9(2), 70-80.

Azka, E. A., Albakir, H., \& Hidayat, C. (2016). Pengaruh Motivasi Karyawan dan Reward terhadap Kepuasan Kerja Karyawan pada PT. UFO BKB Syariah. Universitas Bina Nusantara, 1-8.

Chin C. Lye. (2018). The Influence of Job Satisfaction on Employee Turnover Intention in the Manufacturing Industry of Malaysia. Journal of Arts \& Social Sciences, 1(2), 5363.

Gohari, Kamkar, H. (2015). Relationship Betwen Rewards And Employee Performance: A Mediating Role Of Job Satisfaction. Interdiciplinary Journal Of Contemporary Research In Business, 5(3), 986-995.

Grille, A., Schulte, E., \& Kauffeld, S. (2015). Promoting Shared Leadership: A Multilevel Analysis Investigating the Role of Prototypical Team Leader Behavior, Psychological Empowerment, and Fair Rewards. Journal of Leadership \& Organizational Studies, 22(3), 324-339. https://doi.org/10.1177/1548051815570039

Haile, M., \& Premanandam, P. (2017). Employees 
Job Satisfaction In Ethiopia: A Comparative Study Of Selected Public And Private Sectors In Woldia District. International Journal of Applied Research, 3(4), 19-25.

Inuwa, M. (2015). The International Journal Of Business \& Management The Impact of Job Satisfaction, Job Attitude and Equity on Employee Performance Abstract : The Impact of Job Satisfaction, Job Attitude and Equity on Employee Performance, 3(5), 2011-2016.

Kennedy, K., \& Gray, V. (2015). Employee Job Satisfaction and Engagement. The Society for Human Resources Management.

Khan, G. A., \& Afzal, M. (2016). The Effect of Reward Systems, Organizational Commitment and Experience on Job Satisfaction With Respect to Employee's Perceived Performance. NUML International Journal of Business \& Management, 11(2), 35-49.

Li, J., \& Roessler, R. T. (2017). Factors Influencing Job Satisfaction for Employed Adults With Multiple Sclerosis. Rehabilitation Counseling Bulletin, 61(1), 28-40. https://doi.org/10.1177/0034355216662616

Lo, H. M., \& Nessa. (2016). Exploring the Effect of Staff Achievement on Job Satisfaction in Hong Kong Residential Clubhouse. Journal of Tourism \& Hospitality, 5(6).

Lu, Y., \& Xiao-min. (2017). The Relationship Between Job Satisfaction, Work Stress, Work Family Conflict, And Turnover Intention Among Physicians In Guangdong, China: A Cross-Sectional Study. BMJ, 10(2). https://doi.org/10.1136/bmjopen-2016014894

Luthans. (2011). Organizational Behavior an Evidence Based Approach 12th Edition. Organizational behavior: an edivence-based approach (12th ed.). McGraw-Hill/Irwin.

Luthans, F. (2015). Organizational Behavior (12th Editi). New York: The Mcgrow-Hill Companies Inc.

Malhotra, N. K. (2010). Marketing Research an Applied Orientation. New Jersey: Pearson.

Malik, M. E., Danish, R. Q., \& Munir, Y. (2015). The Impact of Pay and Promotion on Job Satisfaction: Evidence from Higher Education Institutes of Pakistan. American Journal of Economics, (June), 6-9. https://doi.org/10.5923/j.economics. 2012000 1.02
Masood, A., Aslam, R., \& Rizwan, M. (2014). Factors Affecting Employee Satisfaction of the Public and Private Sector Organizations of Pakistan. International Journal of Human Resource Studies, 4(2), 97-121. https://doi.org/10.5296/ijhrs.v4i2.5902

16). Job Satisfaction And Satisfaction In Financial Situation And Their Impact On Life Satisfaction.

Mehrad, A. (2016). Effect of External Factors on Staff Job Satisfaction at Organization. The Online Journal of Counseling and Education, 5(2), 14-22.

Mishra, T. K. G. P. (2013). Promotion As Job Satisfaction, A Study On Colleges Of Muscat , Sultanate Of Oman. European Journal of Business and Management, 5(5), 56-63.

Mohd, C., \& Che, Z. (2017). The Impact Of Multiple Factors In Teachers Job Satisfaction. Journal of Global Business and Social Entrepreneurship (GBSE), 1(2), 20-30.

Mustapha, N., \& Zakaria, Z. C. (2013). The Effect of Promotion Opportunity in Influencing Job Satisfaction among Academics in Higher Public Institutions in Malaysia. International Journal of Academic Research in Business and Social Sciences, 3(3), 20-26.

Prabhakar, A. (2016). Analysis of high job satisfaction relationship with employee loyalty in context to workplace environment. International Journal of Applied Research, 2(4), 640-643.

Ramadhanti, D., Mulyadi, H., \& Razati, G. (2016). Pengaruh Status Sosial Ekonomi Orang Tua Terhadap Sikap Kewirausahaan. Jurnal Pendidikan Manajemen Bisnis, 11(20), 3237.

Saharuddin, \& Sulaiman. (2016). The Effect Of Promotion And Compensation Toward Working Productivity Through Job Satisfaction And Working Motivation Of Employees In The Department Of Water And Mineral Resources Energy North Aceh District. International Journal of Business and Management Invention, 5(10), 33-40.

Seman, K., \& Suhaimi, S. A. (2017). The Relationship Between Financial And NonFinancial Rewards On Employee's Job Satisfaction At Manufacturing Industries In Malaysia. International Journal of Accounting, Finance and Business, 2(5), 1523.

Senen, S. H., Sumiyati, \& Masharyono. (2016). The 
Effect of Skill Variety, Task Identity, Task Significance, Autonomy and Feedback on Job Performance, 15, 585-588.

Senen, S. H., \& Widyanata, R. (2016). Pengaruh Lingkungan Dan Kemampuan Kerja Terhadap Kinerja Karyawan Pt . Ronadamar Sejahtera Cabang Bandung. Journal of Business Management Education, 1(2), 47-55.

Shyam Singh. (2016). Review of Literature on Influence of Job Satisfaction, Employee Compensation, Working Environment on Employee Retentiom. Ijariie, 2(1), 416-421.

Simanjuntak Yulyarta. (2015). Pengaruh Promosi Jabatan Terhadap Kinerja Karyawan Pada PT. Riau Media Grafika. Jom FISIP, 2(2), 1-12.

Singh, P., \& Loncar, N. (2017). Pay Satisfaction, Job Satisfaction and Turnover Intent. Département Des Relations Industrielles De L'université Lava, 65(3).

Srivastav, A. K., \& Das, P. (2013). A Study on Employees Attitude Towards The Organization and Job Satisfaction. International Journal of Science and Research (IJSR) ISSN (Online Index Copernicus Value Impact Factor, 14(7), 2319-7064.

Svendsen, M., \& Unterrainer. (2018). The Effect of Transformational Leadership and Job Autonomy on Promotive and Prohibitive Voice: A Two-Wave Study. Journal of Leadership \& Organizational Studies 1. https://doi.org/10.1177/1548051817750536

Zaheer, Rehman, N. S. A Study Measuring The Effect Of Pay, Promotion And Training On Job Satisfaction In Pakistani Service Industry, MPRA Paper (2013).

Zaraket. (2017). Impact of Financial Rewards on Job Satisfaction and Employee Retention among Employees of Lebanese Banking Sector. Proceedings of Annual Berlin Business Research Conference, 1(2), 1-11.

http://www.compensationforce.com/2017/04/2016turnover-rates-by industry.html diakses diakses 17/12/2017.

www. betahita.id diakses 21/01/2018). 